James Woudhuysen

is director of forecasting at designers Seymour Powell in London and professor of innovation at De Montfort University, Leicester. In 1988, at Fitch, he co-directed Britain's first major study of e-commerce; in 1992, at the Henley Centre for Forecasting, he proposed that the Internet be delivered over TV; between 1995 and 1997 he managed worldwide market intelligence for Philips consumer electronics in the Netherlands.

Keywords: e-commerce, fulfilment, innovation, Internet, brands

\section{E-fulfilment: The opportunities for the future: Part Two}

\author{
James Woudhuysen \\ Received (in revised form): 23 November 2000
}

\begin{abstract}
This, the second of two papers, suggests that even before B2C e-fulfilment has ended its infancy in the UK, its potential looks like being frustrated by the misguided initiatives of government-linked policy makers. Official fears about the environmental and social ructions caused by e-fulfilment threaten its future, and are part of a wider, alarmist climate that both betrays a loss of perspective on B2C e-commerce and is hostile to the genuine progress and innovation that such an enterprise demands. The author ends by dealing with the opportunity for workplace deliveries, the myths that surround both the corner shop as a delivery point and the conventional retailer as a purveyor of leisure experiences, and the need to think as carefully about the physical side of e-commerce as one does about its electronic aspects.
\end{abstract}

\section{Introduction}

The first of these two papers tried to demonstrate that the fulfilment of e-commerce 'tangibles', though difficult, is not impossible. Even the complex job of picking and delivering groceries is economically viable even in Britain, where conventional retailing is highly efficient.

What, then, might still impede success in e-fulfilment? The evidence is that, in the future, feeling about B2C e-fulfilment will turn from suspicion of 'tangibles' and concerns about the economic viability of picking and delivering, to anxiety that e-fulfilment will lead to problems of environmental degradation caused by greater use of transport, and worry that it could exacerbate problems of social exclusion - otherwise known as the 'digital divide'.

This paper will deal with each of these fears in turn.

\section{Fears: Problems of environmental degradation}

Part of the appeal of B2C e-fulfilment to consumers lies in their hope that they will have to make fewer dreary trips to the same old shops. But while consumers can be forgiven for thinking that e-fulfilment might make use of Britain's roads less intensive, authoritative figures fear otherwise. Mick Jackson of the Freight Transport Association has denounced 'the more alarmist predictions of white-van gridlock', but on suburban housing estates, he believes, traffic congestion 'will do nothing to endear the [fulfilment] industry to society at large'. ${ }^{1}$ Sir John Banham, chairman of Kingfisher, is more alarmed: 'we must be certain', he has argued, 'that we 


\section{E-fulfilment an enormous traffic jam}

aren't sleepwalking into the most enormous traffic jam'. ${ }^{2}$ As for the trendy Guardian Online, it is apopleptic:

'It is easy to imagine a scenario where this [B2C e-commerce] results in greater environmental damage, not less - quite apart from the physical dangers from wild van drivers careering up and down our streets.

'Shopping remotely, whether through traditional mail order or new media, is more likely to result in dissatisfaction. The colour isn't quite right, the size is wrong. That means more two-way trips. Then there are the items you forget when skipping down Tesco's screen catalogue, which you would spot on the shelves as you struggle past with the trolley. That is another car journey perhaps.

'Even worse, it is possible that families freed from the chore of Saturday morning supermarketing will hop in the car and whiz miles down the motorway to some leisure paradise for the day. ${ }^{3}$

In finger-wagging style, the chance that successful B2C e-fulfilment might allow families to take extra trips to 'some leisure paradise' is here stigmatised as environmentally unacceptable.

\section{The growing green agenda}

The normally sober Economist has also discovered that B2C e-commerce contains an ecological downside:

'... shopping online from home is far less polluting than driving to a shopping mall. Ordering groceries online, and having them delivered, means that, if the logistics are handled efficiently, one truck journey can replace dozens of families' separate car trips. . Y Yet doing things online is more energy efficient only if it genuinely displaces real-world activities. If people shop online as well as visiting the bricks-andmortar store, the result is an overall increase in energy consumption. Thanks to the Internet, it is now easy for Europeans to order books and have them extravagantly air-freighted from America before they are available in Europe. ${ }^{4}$

That The Economist feels called upon to sneer at its bedrock ideology free trade - is a sign of how influential the green agenda has become in e-commerce.

Its influence in government is particularly ominous. The DTI worries about those people who hit the shops while on another trip, 'which would still be made'. The prospect that grocers might compete around different service delivery schedules is also regarded with apprehension. ${ }^{6}$ And, helped by the Department of Environment, Transport and the Regions, DTI e-commerce Minister Patricia Hewitt has launched 'Digital Futures', a year-long investigation into the environmental implications of e-commerce published as a book with the same title in March 2001.

Digital Futures is sponsored by Amazon, AOL, BT, Ericsson and Sun Microsystems, as well as BP, Kingfisher, Unilever, WHSmith, three financial services companies, three government departments and no fewer than eight think-tanks. It aims to revive the corner shop and lower $\mathrm{CO}_{2}$ 


\section{Government fears vs \\ public good sense}

emissions; neutrally enough, too, it is coordinated by Forum for the Future, a think-tank founded by the environmentalist Jonathon Porritt.

Government fears over the 'sustainability' of a phenomenon that has barely begun stand in sharp contrast, thankfully enough, with consumer sentiment. Research by Lex Transfleet shows that only 38 per cent of nearly 1,700 UK motorists surveyed would oppose B2C e-commerce if it resulted in a rise in the number of vans or trucks delivering goods. ${ }^{7}$ True, these are motorists; but the majority of the UK adult population are motorists. After the petrol 'strike' of summer 2000, there can be little doubt that most British households prefer continued road transport to environmental restrictions upon it.

Let us hope the same good sense goes on prevailing in e-fulfilment.

\section{Fears: Social exclusion}

The final worry about B2C e-commerce concerns social exclusion. Even before fulfilment has really begun, Digital Futures fears that it might lead to greater alienation in Britain. As BT chief executive Peter Bonfield is quoted in a promotional leaflet for Digital Futures, we cannot afford to 'create a technocentric society, detached from the individual'. ${ }^{8}$

Once e-fulfilment is considered, the DTI also gets nervous about the digital divide. When conventional retail outlets find their business diverted to e-commerce, less profitable stores might find their very existence threatened. In turn, that 'could have a negative impact on the availability of retail facilities in deprived neighbourhoods, and so act against recent government initiatives'. ${ }^{9}$ Moreover, the excluded themselves could come to stalk the delivery process:

'How will vulnerable consumers be protected from bogus delivery van drivers? Are there crime prevention issues for the design of vehicles, buildings and the personal security of delivery van drivers?'10

A spectre is haunting e-fulfilment - the spectre of a Wild West on Britain's streets. We can only hope that fear of crime around delivery does not choke e-commerce off at birth.

\section{A sense of perspective}

Melodramatic fears surround B2C e-commerce; it is worth getting the phenomenon in perspective. Forrester Research concludes that just 7 per

In fact, B2C e-commerce will mean little new business cent of UK groceries will go online by $2005 .{ }^{11}$ Verdict estimates that B2C e-commerce, worth $£ 581 \mathrm{~m}$ or just 0.3 per cent of UK retail sales in 1999 , will move up to $£ 8.8$ bn by 2004 , or 3.6 per cent of retail sales. Verdict also believes that digital TV and new technologies such as body scanning will boost online clothes sales ... to $£ 1.2 \mathrm{bn}$, or a mere 2.7 per cent of the sector total, by $2004 .^{12}$

In that year, Verdict predicts, only about 6 per cent of B2C e-commerce will represent new sales growth. Fully 94 per cent will be transferred from existing channels. And this modest diversion effect will in turn only happen if British e-shoppers are convinced that fulfilment can be done at times convenient to them. In October 1999, Verdict reports, 19 per cent of 


\section{B2C will affect individual retailers more than the retail sector}

\section{Concern about 'cannibalisation'}

\section{Goods returned will be critical}

Internet users had a problem with fulfilment schedules. By April 2000, the figure had risen to 25 per cent. $^{13}$

Perhaps both Tesco and Sainsbury can, in their different ways, make some money on their e-commerce and e-fulfilment operations. However, as the first paper showed, the revenues involved - £6m a week in the case of Tesco.com - will be relatively modest. Perhaps, too, some niche retailers in tangibles and some general retailers of intangibles will make some money. For the individual retailer, online success is possible: there will certainly be a market for e-commerce among the 'cash-rich, timepoor' segment of the UK population, and since the digital divide is actually being closed, the general market for e-commerce can be expected to become more universal. ${ }^{14}$ Importantly, too, an individual retailer's failure to go online may hurt both consumer and investor perceptions of the business. But for the retail sector as a whole, e-commerce volumes will have to grow enormously for proper economies of scale ever to be reached. We are dealing here not with a step-change innovation in British retailing, but with a redistribution of sales and profits between different retail players.

\section{More alarms, or real issues?}

Since the demise of boo.com, 'pure-play' e-tailers have moved from being the darlings of the stock market to being objects of derision. McKinsey Europe has also warned of the dangers of 'cannibalising' offline operations in favour of online ones:

'Building an online operation is difficult enough. Making it possible for the new entity to leverage the assets of the traditional business (and most probably cannibalise it) without creating huge organisational tensions or slowing down the new or the old organisations is another enormous challenge. ${ }^{, 15}$

Dismissing today's fashionably wild alarms, however, others have sensibly struck a more optimistic note:

'Old-line enterprises that resist dot.comming because they fear that online sales will cannibalise current revenues have learned that their anxieties are overblown. It is far more likely that online efforts will prove complementary, reaching new customers. ${ }^{, 6}$

To repeat: for the individual retailer, including the 'pure-play' sort, online success is possible. And the retailer may also feel divided on the safety or otherwise of going over to 'trusted third parties' in fulfilment; even though, since Amazon struck a deal with Toys 'R' Us in which the former took fulfilment off the hands of the latter, alliances in which different folks play different strokes could prove a stable solution. ${ }^{15}$ But while all these matters have caused swings of feeling among individual retailers, a much more fundamental and durable issue for the whole retail sector to consider is that of returns. Here McKinsey USA notes that the value of online retailer returns constitutes 11 per cent of all revenue, and that the cost of processing returns constitutes a significantly higher percentage of operating costs. ${ }^{18}$ 


\section{The focus on B2C reveals more about us than about a radical change}

\section{Must e-fulfilment be politically correct?}

B2C e-commerce will not become a reality in Britain until this very real issue is resolved.

\section{Why all the fuss?}

The media obsession with B2C e-commerce says more about the consumer utopias mentioned in the previous paper than it does about real innovation. In the USA, Professor Robert Gordon, an influential sceptic about the 'new economy', observes:

'Much e-commerce is an alternative to mail-order catalogue shopping, yet the catalogues have not disappeared. Indeed, with the exception of the initial step of replacing a human telephone response with a computer interface, e-commerce duplicates all the other costs of catalogue retailing: building and stocking warehouses, selecting items from warehouse shelves, and so on. ${ }^{, 19}$

B2C e-commerce may be just an extra way of doing mail-order shopping, or simply mail order's successor. Either way, it is hard to see what the fuss is all about.

Unrealistic expectations are rife in $\mathrm{B} 2 \mathrm{C}$ e-commerce. Talk of a more direct relationship beween manufacturer and consumer can safely be discounted. As for e-commerce bringing about disintermediation, this is only half the truth. When supply chains are long, new technology may well make some intermediaries disappear. But the emergence of Amazon and lastminute.com also speaks of the emergence of new intermediaries.

For the time being, at least, e-fulfilment systems in the UK remain fragmented, immature and expensive. Of course, the plurality of methods engaged in each of the several stages that comprise 'fulfilment' can make, it has been argued, for more flexibility: a flexibility 'between the old tried-and-tested middleman, the corner shop and the new delivery whippersnappers' ${ }^{20}$ But it could also make for consumer confusion. Naturally, each consumer should only need to fill out most of an electronic retailer's screen-based tickboxes just once; but that is not most people's experience of handling transactions on the Web.

\section{E will stand for ethical}

The potential for consumer confusion, however, should not be exaggerated: to update David Ogilvy's slogan in line with today's demography, 'The consumer is no moron. She is your mother.' Nor do we need another moralising but vacuous discourse on the importance of brands to consumer 'trust'. No: the real barrier to B2C e-fulfilment lies not with consumers, but with today's officialdom's fear that e-fulfilment's environmental and social costs will exact too high a penalty to make it worthwhile.

Already, green zealots hold up a signpost for things to come:

' $\ldots$ one thing is already clear: if the Internet is to play a role in delivering sustainability, we need a fresh wave of e-entrepreneurs willing to channel their skills and creativity for the benefit of all. Then we'll really have something to get dot.com envious about. ${ }^{21}$ 
Workplaces may turn out to be vital CDPs in the future
Experts are

sentimental about local stores as CDPs
The current wave of e-entrepreneurs is anathematised, and calls grow for the right, ethical kind of e-commerce.

Those calls represent a reactionary perspective. They are inimical to innovation and progress. To move debate forward, the author offers four conclusions.

\section{Conclusions (1): The importance of the workplace to e-fulfilment}

The first conclusion is that as a site for delivery, the workplace is probably underestimated. Work has become more commoditised, more casual, yet somehow more dominating in people's lives. Working hours in Britain are long, the number of people at work is rising and the 'work-life balance' is endlessly debated. Later retirement is also on the way. As CDPs, therefore, workplaces are likely to prove important.

Workplaces offer economies of scale in e-fulfilment, and some convenience to employees - provided that people are still able to drive to work and so pack their cars with groceries there. Building workplace CDPs could certainly be considered by major employers as part of today's employee's wider 'compensation package'.22 Already, Waitrose@work targets relatively affluent consumers willing to pay a premium for topquality produce, wine and flowers delivered to any office building with more than 300 PCs. The service allows users to order goods not just by category or name, but by specifying particular recipes.

\section{Conclusions (2): Corner shops as sites for social engineering}

The second conclusion is that while the corner shop is no utopian site for delivery, the government is misty-eyed about its potential. Supermarket chains do not favour local stores as CDPs on the grounds that

- their working practices can be arcane and unhygienic

- their storage facilities would need to be expanded

- dealing with a large number of independent organisations could be a hassle. $^{23}$

Nevertheless, the eulogies now awarded to the local store go well beyond economic rationalism. For Mick Jackson there is joy to be had in 'the King's Arms, Blogg's Newsagent, the Village Stores and the Garage on the Green' ${ }^{24}$ For the Online Research Agency, B2C e-commerce means that 'all sorts of long-forgotten institutions like the corner shop are being revived' ${ }^{25}$ For management consultants Luther Pendragon, the corner shop could be in for a 'reincarnation' - especially if its owners are of Asian descent, since, we are told, such people tend to offer opening times relevant to the Net; in fact the Net could offer 'a lifeline to the high street' because 'the nature of business development is often not unlike Mother Nature. Nothing is wasted. ${ }^{26}$

Significantly, the DTI agrees. It argues that local shops could 'reduce the [shopper's] average trip length, leading to a reduction in congestion and environmental impacts. Such a service could also be of great benefit 


\section{Small stores as CDPs cannot compete with the new force of convenience retailing}

\section{Critics are sentimental about experience retailing}

to the community in the redevelopment of a local economic and social focus. ${ }^{, 27}$ Here the corner shop becomes a temple not so much to e-commerce as to environmental and social engineering.

\section{Corner shop CDPs will be no match for conventional c-stores}

The fear that e-commerce could destroy our dear old British high street is matched only by the equally outlandish hope that, especially in rural areas, the local store can act as a force for social cohesion. So for the government to fasten upon such a target would be a mistake - if, on current form, a very probable one.

Anyway, corner shops - food specialists, CTNs, chemists and offlicences - now face stiff competition from the convenience store and petrol forecourt, each of which is set to expand its range of fresh food and vegetables, its sales and its space. In the future, then, more people will be merely a walk or a short drive away from a reasonable shop. So for the traditional corner shop to act as a successful CDP, it would have to be even closer than the local c-store, open at least as long, and graced with shorter queues. That is an unlikely prospect.

\section{Conclusions (3): The mythology of shopping as a leisurely experience}

The third conclusion is that any revival of 'experience' conventional retailing will have little to do with e-commerce.

In the same measure as hearts leap over B2C e-commerce and the corner shop, so it is argued that $\mathrm{B} 2 \mathrm{C}$ e-commerce should prompt a revival of 'experience' retailing. Thus the popular US architectural critic Bill Mitchell argues:

‘... place-based enterprises will compete for our presence, attention, and dollars in a digitally mediated world by attempting to add as much value as possible to the face-to-face experiences that they offer.

'Local food shops that want to compete with online supermarkets will pitch themselves to the senses, through foodie-magnet displays of produce, nostril-tickling aromas of coffee, spices and baked goods, and tempting tasting stations at every aisle. Those very same shoppers who save time during the week by ordering their detergent and toothpaste from an online supermarket may allocate some of their weekend leisure time to visiting a sophisticated wine and cheese store. ${ }^{28}$

Now there is indeed little fun to be had in buying detergent and toothpaste in the flesh - even if online chemists could be riding for a fall. ${ }^{29}$ However, the story of the British high street in the 1990s has more to do with cost cutting and the boom of leisure operators (Pizza Express, Starbucks) than it has to do with realising the experiential promise set by Debenhams in the 1980s. Despite plenty of hype, British retailing has in practice proved stubbornly resistant to theatrical interpretations, and it will take more than a bit of e-commerce on the side to convert it to a truly thespian course. In bookselling, the commodification of Waterstones over past years shows that McKinsey USA's caution about pure-play Web retailers in that low-margin sector is well founded. ${ }^{30}$ 


\section{Geography gains praise at the expense of cyberspace}

\section{Hopes about experience retailing have little to do with e-commerce}

\author{
Store-based picking \\ makes good sense ...
}

\section{The rehabilitation of place}

Retailing just might move towards experiences, of course. The most obvious candidate is fashion, although in this sector McKinsey USA is optimistic that established operators - and especially those with direct mail experience - can 'make per-order economics much better than they are in any other category we examined'. ${ }^{31}$ Perhaps 'experiences' will be more found among those sectors where e-commerce has already made inroads: housewares (Habitat), IT and consumer electronics (Dixons) and cars (more in the USA than in the UK at present). Clearly people will browse and order goods from the same brand not just on screen, but in person too. However, the sentimentality which now attaches to 'experience' retailing goes further than Mitchell's tickled nostrils. The American management guru Jeremy Rifkin also upholds old-fashioned place in the manner of a man bereaved:

'.. the more connected people become in a range of multifaceted global networks, the less time they have available for the kinds of intimate social relations that can take place only in real time and by way of face-to-face engagement. In a new century dominated by electronically mediated environments, the challenge in every country will be to create new opportunities for direct participation with our fellow human beings in geographic-based communities.

'All real cultures exist in geography because that's where intimacy takes place, and without intimacy it is not possible to create bonds of social trust and engender true feelings of empathy. Resurrecting and revitalising culture, then, means paying at least as much attention to geography as to cyberspace and to participation in real communities as to computer interfacing inside electronic chatrooms. ${ }^{, 32}$

The argument about place-based 'experience' retailing makes reference, then, to e-commerce only rhetorically. Its real roots lie in our sense of loss, in the corrosion caused by unrestrained market forces that underlies this, and in our misplaced desire to seek redress in a playful but ultimately unfulfilling round of see-and-be-seen rituals.

B2C e-commerce and fulfilment cannot be blamed for alienation. The antidote for alienation lies as little with the 'experience' retailer as it does with the corner shop.

\section{Conclusions (4): Let's get physical}

The final conclusion is that $\mathrm{B} 2 \mathrm{C}$ e-commerce problems can be solved, provided that the real, physical world is granted the same attention now given to the world of 'pure navigators'.

If the BCG analysis with which the first paper began was a fair one, it would follow that the future of B2C e-commerce would primarily lie with intangibles, not tangibles. That might prove the case in practice; but if it did, it would mean that the development of the Internet had taken place in a manner entirely separate from the development of physical infrastructure.

Of course, it can be argued that Tesco.com has 'Amazoned' its offering by extending its wares to include books and CDs. In this sense, it 


\section{... but dedicated picking centres may be the big prize}

\author{
Big tasks remain in \\ physical, not virtual \\ technologies
}

becomes a trusted, branded navigator $\grave{a}$ la $\mathrm{BCG}$; and if navigators do indeed own the future, Tesco's decision to opt for a relatively modest store-based picking model would be entirely correct.

However, it is no insult to Britain's market-leading grocer to point out that, for $\mathrm{B} 2 \mathrm{C}$ e-commerce genuinely to make an improvement on people's lives, issues of economics, returns and product substitutions favour automated picking from dedicated sites. To its credit, the DTI's Retail Logistics Task Force recognises the 'large economies of scale' that would follow from ambitious, national e-commerce picking centres at central warehouses. ${ }^{33}$ Indeed, this may be the only way that e-fulfilment of groceries can really be made to work.

To its additional credit, the task force outlines the very tangible technological challenges that lie ahead. We need kitchen appliances, beyond the Electrolux advertisements, that really do automatically reorder goods that have been used. We need order-tracking systems that tell us when items are out of stock, and that allow us to change our minds at the last minute before despatch. We need new delivery vehicles, a new genre of unattended goods reception devices for both home and CDP, and a lot more attention to storage materials and temperature control. ${ }^{34}$ As McKinsey USA has noted in a general study of logistics, the use of IT to guide trucks and forklifts to different gates at a warehouse ('dock scheduling'), and, above all, automated picking and quality control systems are the chief things that distinguish high-performing service providers from low-performing ones. 35

Any other programme for e-fulfilment amounts to little more than Platonic idealism. To make a difference, interactive marketers should dispense with that philosophy, and instead start to get physical.

\section{Acknowledgments}

The author is grateful to Kirsten A Boehner of Strategos UK, for her help with this paper.

\section{References}

1. Jackson, M. (2000) 'Local solution eases delivery', Retail Week, 23 June.

2. Quoted in Clements, A. (2000) 'The road to white van gridlock?', Retail Week, 21 July.

3. Cowe, R. (2000) 'Dark side of the Web', The Guardian, 24 February.

4. The Economist (2000) 'What the Internet cannot do', 19 August.

5. DTI Retail Logistics Task Force (2000) @ Your Service: Future Models of Retail Logistics, DTI, p. 9.

6. Ibid., p. 18.

7. Lex Transfleet (2000) The Lex Transfleet Report on Freight 2000, p. 33 (see www.lextransfleet.co.uk).

8. Quoted in 'Forum for the Future' (2000) Digital Futures: e-commerce, society, environment. See www.digitalfutures.org.uk

9. DTI Retail Logistics Task Force, ref. 5 above, p. 10.

10. Ibid., p 19. 
11. Forrester Research (2000) Online Grocers Diversify, June. See www.forrester.com.

12. Verdict (2000) Electronic Shopping 2000. See www.verdictonline.co.uk.

13. Ibid.

14. 'Internet usage by blue-collar and manual workers has almost doubled since May 1999, making this the fastest growing group online. Of all C2Ds, 15 per cent now use the Internet regularly, catching up with the 39 per cent of ABC1s online.' Forrester Research (2000) UK Internet User Monitor, June. See www.forrester.com.

15. Cornet, P., Milcent, P. and Roussel, P-Y. (2000) 'From e-commerce to Euro-commerce', The McKinsey Quarterly, No. 2, Europe. See http://mckinseyquarterly.com.

16. Skarzynski, P. and Tchen, C. (2000) 'Merging bricks and clicks', Wall Street Journal Europe, 28 August, p. 9.

17. DTI Retail Logistics Task Force, ref. 5 above, p. 19; Neumann, C-S. (2000) 'Best practice in logistics', The McKinsey Quarterly, No. 3, p. 21.

18. Bhise, H., Farrell, O., Miller, H., Vanier, A. and Zainulbhai, A. (2000), 'The duel for the doorstep', The McKinsey Quarterly, No. 2.

19. Gordon, R. (2000) 'Not much of a new economy', Financial Times, 26 July.

20. Azeez, W. (2000) 'Deliver us from e-mail', Guardian Online, 22 June, p. 6.

21. Green Futures (2000) 'So where's the ethics.com?', May/June.

22. The argument here is only a brief one, and naturally does not cover the problem of delivering to small and medium sized enterprises (SMEs). It draws upon Woudhuysen, J. (2000) Space Futures 2000: Office space - The myths and the realities, Milliken Carpet.

23. DTI Retail Logistics Task Force, ref. 5 above, p. 22.

24. Jackson, ref. 1 above.

25. Quoted in Azeez, ref. 20 above.

26. Pitcher, G. (2000) 'Why e-tailers are turning to high street distribution', Marketing Week, 22 June.

27. DTI Retail Logistics Task Force, ref. 5 above, pp. 21-22.

28. Mitchell, W. (2000) E-topia, MIT Press, p. 142.

29. Barsh, J., Crawford, B. and Grosso, C. (2000) 'How e-tailing can rise from the ashes', The McKinsey Quarterly, No. 3, pp. 103, 105.

30. Ibid pp. 103, 104.

31. Ibid., p. 106.

32. Rifkin, J. (2000) The Age of Access, Tarcher/Putnam, pp. 252-253.

33. DTI Retail Logistics Task Force, ref. 5 above, p. 17.

34. Ibid., pp. 17, 23, 24.

35. Neumann, ref. 17 above, pp. 19-21. 